\title{
Social Work Overview of The Society on The Individual Using Addictive Substance: Case of Manisa
}

\author{
Sosyal Hizmet Bakış Açısından Bağımlılık Yapıcı Madde \\ Kullanan Bireylere Yönelik Toplumun Bakışı: Manisa Örneği
}

\author{
Gözde Y1lmaz ${ }^{1}$, Derya Şaşman Kaylı²
}

\begin{abstract}
:
This study was conducted to examine society's attitudes towards individuals using addictive substances and the factors affecting these attitudes within the framework of the biopsychosocial model and anti-discrimination social service perspective. In this descriptive correlational study, was conducted in Manisa city center on a sample of 396 and a questionnaire developed by the researcher was used as data collection tool, and the collected data was analyzed in IBM SPSS 25.0 software program. It had been determined that the participants who have no relatives who have experienced addiction treatment and who use alcohol and drugs, have more social distance and more negative behaviour towards individuals using addictive substances. It had been found that the participants' use of smoking, alcohol and narcotoc drugs are also important factors affecting their thinkimg and behavior towards these individuals. In this respect, micro, mezzo and macro social service interventions, which have a holistic perspective in the field of drug addiction, aim at empowering addicts and increasing their social functionality, facilitating access to resources, and combating existing exclusionary attitudes and political arrangements are also very important in solving this problem.
\end{abstract}

Key Words: Addiction, Anti-Discrimination Social Work, Biopsychosocial Model

${ }^{1}$ Manisa Celal Bayar University, Faculty of Health Sciences Department of Social Work Master Student, Orcid İd: https://orcid.org/ 0000-0002-3331-9304

${ }^{2}$ Assoc. Prof., Manisa Celal Bayar University, Faculty of Health Sciences Department of Social Work, Orcid İd: https://orcid.org/ 0000-0001-7949-2332

Address of correspondence/Yazışma adresi: Manisa Celal Bayar University, Faculty of Health Sciences Department of Social Work Master Student, E-mail: yilmazggozde@gmail.com

Date of Received/Geliş Tarihi: 25.02.2020, Date of Revision/Düzeltme Tarihi: 16.08.2020, Date of Acceptance/Kabul Tarihi: 18.08.2020, Date of Online Publication/Çevirimiçi Yayın Tarihi: 22.09.2020

Citing/ Referans Gösterimi: Y1lmaz, G., Şaşman Kaylı, D. (2020). Social Work Overview of The Society on The Individual Using Addictive Substance: Case of Manisa, Cyprus Turkish Journal of Psychiatry \& Psychology, 2(3): 148-54.

(C) 2020 The Author(s). Published by Cyprus Mental Health Institute / Cyprus Turkish Journal of Psychiatry and Psychology (www.ktppdergisi.com). This article is an open access article distributed under the terms and conditions of the Creative Commons Attribution 4.0 license which permits use, sharing, adaptation, distribution and reproduction in any medium or format, provided the original work is properly cited and is not used for commercial purposes. http://creativecommons.org/licenses/by/4.0/ 


\section{Özet:}

$\mathrm{Bu}$ çalışma, biyopsikososyal model ve ayrımcılık karşıtı sosyal hizmet perspektifi çerçevesinde toplumun bağımlılık yapıcı madde kullanan bireylere yönelik tutumları ve bu tutumları etkileyen etmenlerin incelenmesi amacıyla yapılmıştır. Tanımlayıcı ilişsisel türde olan bu araştırmada, Manisa merkezde çalışmaya gönüllü olarak katılmayı kabul eden 396 kişi yer almış, veri toplama aracı olarak araştırmacılar tarafından geliştirilen anket formu kullanılmış ve veriler SPSS 25 programıyla analiz edilmiştir. Alkol ve uyuşturucu madde kullanan, bağımlılık tedavisi görmüş bir yakını bulunmayan katılımcıların bağımlılık yapıcı madde kullanan bireylere yönelik daha fazla sosyal mesafe oluşturduğu ve olumsuz davranışlarının daha fazla olduğu tespit edilmiştir. Katılımcıların sigara, alkol ve uyuşturucu madde kullanma durumlarının da bu bireylere yönelik düşünce ve davranışları etkileyen önemli faktörler olduğu bulunmuştur. Bu çerçevede, madde bağımlılığı alanında bütüncül bir bakış açısına sahip olan, bağımlı bireyleri güçlendirmeyi ve sosyal işlevselliğini arttırmayı, kaynaklara erişimini kolaylaştırmayı, var olan dışlayıcı tutumlarla mücadele etmeyi hedefleyen mikro, mezzo ve makro boyuttaki sosyal hizmet müdahalelerinin bağımlılı̆̆ın önlenmesi ve tedavi edilmesinde önemli olduğu düşünülmektedir.

Anahtar Kelimeler: Bağımlılık, Ayrımcılık Karşıtı Sosyal Hizmet, Biyopsikososyal Model

\section{Giriş}

Bağımlılık, bireyin fizyolojik, psikolojik ve sosyolojik yapısını olumsuz etkileyen bir beyin hastalığı olmasının yanı sıra toplumsal sorunları tetikleyen çok boyutlu bir sosyal sorun olarak karşımıza çıkmaktadır. Madde bağımlılığı sorunu da bu anlamda bağımlı bireyin içinde bulunduğu aile ve toplumla, tedavi sürecinde faydalanabileceği kurum ve kuruluşlarla, bu sorunu ele alan politikalarla yakından ilişkilidir.

Bağımlı bireylerin yaşadığı fiziksel ve psikolojik sorunlara ek olarak intihar, şiddet ve suç davranışları içine girebilmeleri, aileleri ve sosyal çevreleri için risk oluşturabilmekte ve bu örüntüde toplum bağımlı bireylere yönelik olumsuz tutumlar geliştirebilmektedir (Özden, 1992; Klingemann, 1999). Bu olumsuz tutumlar madde bağımlısı bireylerin toplumdan dışlanmasına, barınma, istihdam ve eğitim gibi hizmetlere erişimlerinin sınırlandırılmasına neden olabilmektedir. Bu açıdan bakıldığında sosyal adalet ve insan hakları kavramlarını temel alarak insanların iyilik halini, toplumun refahını yükseltmeyi hedefleyen, kişiler arası ilişkilerle, sosyal politikalarla ve sağlı hizmetleriyle bağlantılı olan sosyal hizmet mesleği, madde bağımlılı̆̆ sorunuyla doğrudan ilişkilidir. Günümüzde, bireylerin toplumla ve toplumun kültürüyle iletişiminin zayıflaması, medyada uyușturucu madde kullanan rol ve modellere ilişkin temsillerin artması gibi birçok faktör madde kullanımının artmasına ve sosyokültürel farklılıkları aşarak birçok ülkenin karş1 karşıya kaldığı uluslararası bir sorun haline gelmesine neden olmuştur (Işı1k, 2013; Dumas ve Hennessey, 1999; Vatandaş, Can, Mahitapoğlu, Yaman ve Kırbaşoğlu, 2016). Birleşmiş Milletler Uyuşturucu Suç Ofisi'nin (UNODC) verilerine göre uyuşturucu kullanımının dünyada 275 milyona yükseldiği, Türkiye Uyușturucu ve Uyuşturucu Bağımlılığı İzleme Merkezi' nin (TUBİM) verilerine göre ise ülkemizde uyuşturucu madde kullanan kişi sayısının $1338(\% 3.1)$ olduğu ve en yüksek oranla \%35.4'ünün 15-24 yaş grubundan oluştuğu tespit edilmiştir (UNODC, 2018; TUBIM, 2019). Türkiye'nin uyuşturucu madde üreten ve tüketen bölgeler arasında yer alarak köprü işlevi görmesi (Akgül ve Kaptı, 2010), madde kullanım yaşının küçük yaşlara kadar düşmesi ülkemizi bağımlılık yapıcı madde tüketimi konusunda hedef ülke konumuna getirerek büyük risk oluşturmakta ve madde bağımlılığı konusunu önemli kılmaktadır.

\section{Toplumun Bağımlı Bireylere Yönelik Tutum ve Davranışları}

Madde kullanımı toplum tarafindan, ahlaksızlık ve karakter zayıflığı kavramları ile bütünleştirilmekte ve bağımlılık yapıcı madde kullanan bireylere sosyal uzaklık arzusu beslenmektedir (Husak, 2004, Boekel, Brouwers, Weeghel ve Garretsen, 2015). Yapılan birçok araştırmada da madde bağımlısı bireylerin tehlikeli, saldırgan ve öngörülemez olarak algılandıkları, herhangi bir işi sürdürebilme ve iletişim kurabilme potansiyellerine yönelik beklentilerin düşük olduğu tespit edilmiştir (Corrigan, Kuwabara ve O'Shaughnessy, 2009; Boekel ve ark., 2015; Link, Phelan, Bresnahan, Stueve ve Pescosolido, 1999; Tamar 2001; Janulis 2010).

Bağımlılığın oluşması ile birlikte aile üyeleri arasında bağımlı bireyler kötü karakter özellikleri ile bağdaştırılmakta ve genellikle ailenin destek mekanizmalarından mahrum birakılmaktadır (Toronto Drug Strategy Implementation Panel, 2010). Ailede başlayan damgalama sürecinin tedavi sırasında sağlık hizmeti sağlayıcıları tarafından da uygulandığı ve sağlık hizmeti sağlayıcılarının madde kullanım sorunları olan bireyleri reddetme oranının diğer hastalara kıyasla daha yüksek olduğu görülmektedir (Boekel ve ark., 2015; Meltzer, Suppes, Burns, Shuman, Orfanos, Sturiano ve Fins, 2013; Ronzani, Higgins ve Furtado, 2009). Benzer şekilde, bağımlı bireylerin suç potansiyeli yüksek kişiler olarak görülmesi emniyet mensubu kişiler tarafından damgalanmasına ve bu bireylerin işlemedikleri suçlardan sorumlu tutulmasına sebep olabilmektedir (Toronto Drug Strategy Implementation Panel, 2010). Toplumsal damgalamanın bağımlı bireyde dışlanmışlık hissi, düşük özsaygı ve depresyon gibi sorunlara neden olması bireyin sosyal işlevselliğini azaltmakta ve tedavi seyrini olumsuz etkilemektedir (Türkmen, Kumaşoğlu ve Akyol, 2015). 


\section{Sosyal Hizmet ve Madde Bağımlılığı İlişkisi}

Sosyal hizmet; sosyal adaleti ve insan onurunu temel alarak bireylerin, ailelerin ve toplulukların iyilik halini artırmayı amaçlayan bir bilim ve bir meslektir (Sheafor ve Horejsi, 2016; Farley, Smith ve Boyle, 2003; Zastrow, 2013). Toplumun olumsuz tutumlarından kaynaklanan sosyal bölünmelerin ve eşitsizliklerin ortadan kaldırılmasını, dezavantajlı konumda olan kişilerin baş etme kapasitelerini ve işlevselliklerini arttırmayı, onları güçlendirmeyi görev edinmektedir (Okitikpi ve Aymer, 2010; Tuncay ve İl, 2006). Bağımlılık yalnızca bireysel çıktıları olmayan, bağımlı bireyin ailesini ve sosyal çevresini de psikososyal açıdan olumsuz etkileyen bir hastalıktır. Sosyal hizmet uygulamasının temelini oluşturan ekolojik çerçeve bu anlamda bireyi, etkileşim içinde bulunduğu çevre içinde ele alarak değişime olumlu destek verecek tüm kaynakları göz önünde bulunduran, tıbbi, psikolojik ve sosyal boyutlariyla bir arada ele alan biyopsikososyal modeli kullanmaktadır (Galvani, 2015; Sevin ve Erbay, 2008; De Angelis, 1991). Dolayısıyla sosyal hizmet, madde bağımlılarının sosyal dışlanmasını engelleyecek ve toplumla yeniden bütünleşmesini sağlayacak müdahale planlarında da rol ve sorumluluk sahibidir. Bağımlı bireylere yönelik ayrımcı tutumların önlenebilmesi ve bu bireylerin sosyal haklardan faydalanabilmesi için toplumun bağımlı bireylere yönelik davranışlarını ve bu davranışların nedenlerini tespit etmek son derece önemlidir ve ülkemizde söz konusu konuyla ilgili araştırmaların oldukça sınırlı olması, bu alana yönelik çalışmaları önemli kılmaktadır.

\section{Yöntem}

$\mathrm{Bu}$ araştırma, biyopsikososyal model ve ayrımcılık karşıtı sosyal hizmet perspektifi çerçevesinde, toplumun bağımlılık yapıcı madde kullanan bireylere yönelik davranışlarının ve bu davranışları etkileyen etmenlerin incelenmesi amacıyla yapılmış tanımlayıcı ilişkisel türde bir çalışmadır.

\section{Evren ve Örneklem}

Araştırma, Manisa il merkezinde 1 Şubat 2019- 28 Mayıs 2019 tarihleri arasında gerçekleştirilmiş olup, en geniş örneklem büyüklüğü için beklenen frekans \%50 kabul edilerek, \%95 güven aralığ 1 ve \pm 5 sapma ile minimum örneklem büyüklüğü 384 olarak hesaplanmış ve araştırma, çalışmaya gönüllü olarak katılmayı kabul 396 kişi ile gerçekleştirilmiştir. Katılımcılardan aydınlatılmış onam formu alınmıştır. Küme örnekleme yöntemi kullanılarak Manisa merkezde bulunan 57 mahallenin her biri küme olarak kabul edilmiş ve aralarından random olarak seçilen 8 mahallede araştırma yürütülmüştür. Araştırma gerçekleştirilmeden önce Manisa Celal Bayar Üniversitesi Sosyal ve Beşeri Bilimler Bilimsel Araştırma ve Yayın Etiği Kurulu'ndan onay alınmıştır.

\section{Veri Toplama Araçları}

Sosyodemografik bilgi formuyla birlikte, toplumun bağımlılık yapıcı madde kullanan bireylere yönelik tutumlarını inceleyen bir ölçek bulunamamış olmasından dolayı literatürden faydalanarak oluşturulmuş 33 soruluk bir form kullanılmıştır. Form, bağımlılık yapıcı madde kullananların kişilik özellikleri, bu kişilerle ikili ilişkiler, bu kişilere sosyal ve toplumsal bakış açısı, bağımlılık yapıcı madde kullanmaya ve tedaviye yönelik görüşler olmak üzere dört temel başlık altında oluşturulmuştur. Soruların anlaşılır olup olmadığını tespit edebilmek için 20 kişiye ön test uygulanmış, herhangi bir sorunla karşılaşılmadığı gözlemlenmiş ve diğer katılımcılara uygulanmaya devam edilmiştir. 5'li likert formatında oluşturulan formda yüksek sira ortalaması puanı daha fazla olumsuz tutumu ve damgalamayı temsil etmektedir.

\section{Veri Analizi}

Araştırmada toplanan veriler SPSS 25.0 programıla analiz edilmiş olup verilerin istatistiksel analizinde anlamlılık düzeyi $\mathrm{p}<0,05$ olarak kabul edilmiştir. Verilerin iç tutarlılık ve çarpıklık değerleri Lind, Marchal ve Wathen (2006) tarafından geliştirilen \pm 2 değer aralığ dikkate alınarak incelenmiş, Kolmogorov-Smirnov testi sonrasında verilerin normal dağılmadığı tespit edilmiş, non-parametrik testlere gidilmiştir. Değişkenler arasındaki istatistiksel ilişkiler ki-kare, Mann Whitney U testi, Kruskal Wallis $\mathrm{H}$ testi kullanılarak incelenmiş, ilişkili bulunan değişkenlerin arasındaki ilişkinin gücünü ve yönünü ölçmek amaciyla da korelasyon ve regresyon testleri uygulanmıştır.

\section{Bulgular}

Araștırmaya katılanların, \%56,1'inin $(\mathrm{n}=222)$ kadın ve $\% 43,9$ 'unun $(n=174)$ erkek olduğu, en küçüğ̈̈ 18 ve en büyügü 82 yaşında olmak üzere çoğunluğu $\% 41,7$ $(n=165)$ oranla $31-43$ yaş arası ve $\% 32,1(n=127)$ oranla 18-30 yaş aras1 oluşturduğu, en yüksek oranlarla \%46'sının $(\mathrm{n}=182)$ üniversite, \%36,6'sının $(\mathrm{n}=145)$ ortaöğretim mezunu olduğu görülmektedir. Katılımcıların yarısından fazlası evlidir ve \%58'i $(n=229)$ çocuk sahibidir.

Katılımcıların yarısından çoğu Manisalı olmakla birlikte $\% 16$ 'sinın ( $n=64)$ memuriyet tayini ile ve \%15'inin (n=61) ekonomik sebepli göçle Manisa'ya yerleştiği tespit edilmiştir. Katılımcıların \%37'si $(n=145) 3001$ 5000 tl aras1 ve \%35'i $(n=138)$ 15001-3000 tl aras1 aylık gelire sahipken, \%36's1 (n=141) memur, \%23'ü (n=91) işçi ve \%12'si (n=49) ev kadınıdır.

Tablo 1'de de görüldüğü üzere katılımcıların \%42'sinin $(n=168)$ sigarayı \%60,1'inin $(n=238)$ alkolü hiç kullanmadığı tespit edilmiştir. Katılımcıların \%37'si $(n=146)$ hem alkol hem de sigara kullanırken, \%24'ü $(\mathrm{n}=93)$ sigara kullanıp alkol kullanmamaktadır. Katılımcıların \%95,7'sinin ( $\mathrm{n}=379)$ hayatı boyunca hiç uyuşturucu madde kullanmadığı, \%11'inin $(n=44)$ ailesinde ve yakın çevresinde uyuşturucu madde kullanan ve $\% 6,3$ 'ünün $(n=25)$ yakın çevresinde alkol veya madde bağımlılı̆̆ tedavisi görmüş birinin olduğu tespit edilmiştir. 
Tablo 1. Katılımcıların Sigara ve Alkol Kullanma Durumları

\begin{tabular}{|c|c|c|c|c|c|c|}
\hline DEĞİŞKENLER & Kadı & & Erkek & & Toplar & \\
\hline & SAY] & YÜZDE & SAYI & YÜZDE & SAYI & YÜZDE \\
\hline Sigara Kullanma Durumu & & & & & & \\
\hline Hiç kullanmadım & 115 & $\% 51,8$ & 53 & $\% 30,5$ & 168 & $\% 42,4$ \\
\hline Yılda birkaç kez & 27 & $\% 12,2$ & 18 & $\% 10,3$ & 45 & $\% 11,4$ \\
\hline Ayda bir paket & 9 & $\% 4,1$ & 10 & $\% 5,7$ & 19 & $\% 4,8$ \\
\hline Haftada bir paket & 25 & $\% 1,3$ & 14 & $\% 8$ & 39 & $\% 9,8$ \\
\hline $\begin{array}{l}\text { Hemen hemen her gün bir pakete } \\
\text { yakın }\end{array}$ & 44 & $\% 19,8$ & 72 & $\% 41,4$ & 116 & $\% 29,3$ \\
\hline Bıraktım & 2 & $\% 0,9$ & 7 & $\% 4$ & 9 & $\% 2,3$ \\
\hline Alkol Kullanma Durumu & & & & & & \\
\hline Hiç kullanmadım & 152 & $\% 68,5$ & 86 & $\% 49,4$ & 238 & $\% 60,1$ \\
\hline Yılda birkaç kez & 52 & $\% 23,4$ & 52 & $\% 29,9$ & 104 & $\% 26,3$ \\
\hline Ayda bir & 14 & $\% 6,3$ & 16 & $\% 9,2$ & 30 & $\% 7,6$ \\
\hline Haftada bir & 3 & $\% 1,4$ & 14 & $\% 8$ & 17 & $\% 4,3$ \\
\hline Hemen hemen her gün & 1 & $\% 0,5$ & 5 & $\% 2,9$ & 6 & $\% 1,5$ \\
\hline Bıraktım & 0 & $\% 0$ & 1 & $\% 0,6$ & 1 & $\% 0,3$ \\
\hline Toplam & 222 & 100 & 174 & 100 & 396 & 100 \\
\hline
\end{tabular}

Katılımcıların, madde kullanımına sebep olan etkenlere ilişkin görüşleri Grafik 1'de verilmiştir, \%81'lik oranla arkadaş çevresinin ve \%60'lık oranla da merak faktörünün madde kullanımına başlamada etkili olduğu görüşü hakimdir.

Grafik 1. Madde Kullanımına Neden Olabilecek Faktörler

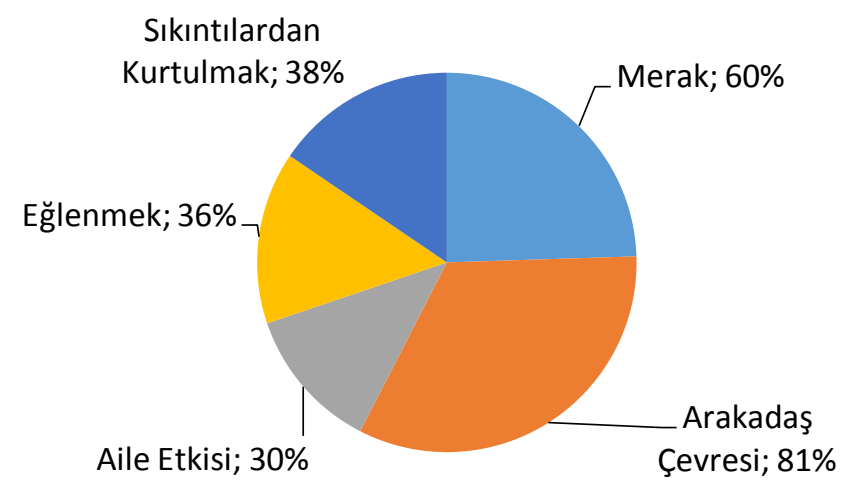

Tablo 2'de, Mann Whitney U testine göre değişkenlerin sıra ortalamaları incelendiğinde, ailesinde madde kullanan birisi olması durumunda erkeklerin kadınlardan daha çok utanacağı ve kadınların bu bireylerden korkma oranının erkeklerden daha yüksek olduğu görülmektedir.

Bunun yanı sıra çocuk sahibi olan katılımcıların madde kullanan kişilerin karakterlerinin gelişmemiş olduğu ve ailesinde böyle biri olması durumunda utanacağı şeklindeki olumsuz düşünceleri çocuk sahibi olmayan katılımcılardan daha yüksektir.

Tablo 2. Katılımcıların Cinsiyetlerinin ve Çocuk Sahibi Olma Durumlarının Yasa Dışı Madde Kullanan Bireylere Yönelik Düşüncelerine Etkisi

\begin{tabular}{|c|c|c|c|c|c|c|}
\hline Sorular & Değișkenler & $\mathbf{N}$ & Sira Ortalaması & $\mathbf{U}$ & $\mathbf{z}$ & p \\
\hline \multirow{2}{*}{$\begin{array}{l}\text { Ailemde bağımlılık yapıcı madde } \\
\text { kullanan birisi olsa, utanırım. }\end{array}$} & $\begin{array}{l}\text { Cinsiyet } \\
\text { Kadın } \\
\text { Erkek }\end{array}$ & $\begin{array}{l}222 \\
174\end{array}$ & $\begin{array}{l}185,28 \\
215,36\end{array}$ & 16379 & $-2,665$ & 0,008 \\
\hline & $\begin{array}{l}\text { Çocuk sahibi olma } \\
\text { durumu } \\
\text { Var } \\
\text { Yok } \\
\end{array}$ & $\begin{array}{l}229 \\
167 \\
\end{array}$ & $\begin{array}{l}210,20 \\
182,46\end{array}$ & 16442 & $-2,445$ & 0,014 \\
\hline $\begin{array}{c}\text { Bağımlılık yapıcı madde } \\
\text { kullanan kişilerin kişiliklerinin } \\
\text { gelişmemiş olduğunu } \\
\text { düşünürüm. }\end{array}$ & $\begin{array}{l}\text { Çocuk sahibi olma } \\
\text { durumu } \\
\text { Var } \\
\text { Yok }\end{array}$ & $\begin{array}{l}229 \\
167\end{array}$ & $\begin{array}{l}209,43 \\
183,51\end{array}$ & 16619 & $-2,291$ & 0,022 \\
\hline $\begin{array}{c}\text { Bağımlılık yapıcı madde } \\
\text { kullanan kişilerden korkarım. }\end{array}$ & $\begin{array}{l}\text { Cinsiyet } \\
\text { Kadın } \\
\text { Erkek }\end{array}$ & $\begin{array}{l}222 \\
174\end{array}$ & $\begin{array}{l}218,51 \\
179,79\end{array}$ & 15640 & $-3,557$ & 0,000 \\
\hline
\end{tabular}


Katılımcıların eğitim düzeyleri yükseldikçe, bağımlı bireylere tedavi sürecinde yardımcı olabileceklerine yönelik puanlarının arttığı tespit edilmiştir (Kruskal Wallis $\mathrm{H}$ testi, $\left.\mathrm{x}^{2}=12,379 ; \mathrm{p}<0,05\right)$. Bağımlı bireylere tedavi sürecinde yardımcı olabilme düşüncesi üzerinde katılımcıların aylık gelir düzeylerinin de etkili olduğu ve aylık gelir düzeyi yükseldikçe bu bireylere yardım edebileceklerine yönelik puanlarının azaldığı tespit edilmiştir $\left(\mathrm{x}^{2}=24,828 ; \mathrm{p}<0,05\right)$. Tedavi sürecinde yardımcı olabilme düşüncesi ile aylık gelir düzeyi arasındaki korelasyonun negatif olduğu görülmüştür ( $\mathrm{r}=$ $0,413 ; \mathrm{p}<0,05)$. Regresyon analizi sonucunda da bu iki değişken arasında negatif yönlü bir ilişki olduğu görülmüş ve katılımcıların aylık gelir düzeyi yükseldikçe BYM kullanan bireylere tedavi sürecinde yardım edebileceklerine yönelik puanlarının azaldığ 1 bulunmuştur $\left(R^{2}=0,051 ; p<0,05\right)$. Katılimciların aylık gelir düzeyi arttıkça, ailelerinde madde kullanan biri olması durumunda utanç duyacaklarına yönelik puanların da arttığl görülmüştür $\left(\mathrm{x}^{2}=11,522 ; \mathrm{p}<0,05\right)$.

Yapılan Kruskal Wallis H testi sonucunda; katılımcıların bağımlılık yapıcı madde kullanan bireylerin tehlikeli insanlar olduğuna (Sigara $x^{2}=31,634$; Alkol $x^{2}=21,073$; Uyuşturucu $x^{2}=13,423$ ) kendi hayatları ile ilgili doğru kararlar alamayacaklarına (Sigara $x^{2}=15,309$; Alkol $\mathrm{x}^{2}=22,705$; Uyuşturucu $\left.\mathrm{x}^{2}=19,635\right)$ suç işleme olasılıklarının daha fazla olduğuna (Sigara $x^{2}=24,572$; Alkol $x^{2}=27,437$; Uyuşturucu $x^{2}=16,849$ ), bu durumun bir hastalık olduğuna (Sigara $x^{2}=12,922 ; \quad$ Alkol $\mathrm{x}^{2}=12,902$; Uyuşturucu $\mathrm{x}^{2}=19,010$ ), bu bireylerle sohbet edip ilişki kurulabileceğine (Sigara $x^{2}=22,904$; Alkol $\mathrm{x}^{2}=31,399$; Uyuşturucu $\mathrm{x}^{2}=18,663$ ), bu kișilerden uzak durmaya çalıştı̆̆ına (Sigara $x^{2}=12,705$; Alkol $x^{2}=18,735$; Uyuşturucu $\mathrm{x}^{2}=12,420$ ) ve ailesinde madde kullanan birinin olması durumunda utanacağına (Sigara $x^{2}=17,978$; Alkol $x^{2}=23,390 ; \quad$ Uyuşturucu $\left.x^{2}=19,454\right)$ yönelik düşünceleri ile sigara, alkol ve uyuşturucu madde kullanma durumları arasında istatistiksel açıdan anlamlı bir farklılık tespit edilmiştir $(\mathrm{p}<0,05)$. Sıra ortalamaları incelendiğinde katılımcıların sigara, alkol ve uyuşturucu madde kullanma sıklıkları arttıkça madde kullanımını bir hastalık olarak kabul edilme oranının ve olumsuz davranışların azaldığı tespit edilmiştir. Bunun yanı sıra katılımcıların uyuşturucu madde kullanmış olmalarının bu bireylerin sözüne güven olmayacağı yönündeki düşüncelerine ait puanları azalttığı $\left(x^{2}=14,018\right)$, alkol $\left(x^{2}=12,306\right)$ ve uyuşturucu madde $\left(x^{2}=18,367\right)$ kullanıor olmalarının bağımlı bireylerin herhangi bir işte çalışmaması gerektiği yönündeki düşüncelerine ait puanlar1 azalttığ 1 , sigara $\left(x^{2}=13,457\right)$ ve alkol $\left(x^{2}=14,103\right)$ kullanma sıklıkları arttıkça da bağımlı bireylerin kullandıkları maddeyi bırakmayacaklarına yönelik düşüncelerine ait puanların azaldığı tespit edilmiştir.

Araştırma çerçevesinde yapılan Mann Whitney U testi sonucunda, ailesinde alkol, uyuşturucu madde kullanan ve bağımlılık tedavisi görmüş biri bulunan katılımcıların bu bireylerin tehlikeli olduğu (Alkol kullanan; $\mathrm{U}=15865$, Uyuşturucu kullanan; $\mathrm{U}=3551$, Tedavi gören; $\mathrm{U}=2547$ ), suç işleme potansiyellerinin yüksek olduğu (Alkol kullanan; $U=17436$, Uyuşturucu kullanan; $U=4376$, Tedavi gören; $\mathrm{U}=3045$ ), bu kişilerden korktuğu (Alkol kullanan; $U=15640$, Uyuşturucu kullanan; $U=4228$, Tedavi gören; $\mathrm{U}=2010)$ ve ailesinde madde kullanan biri olsa utanacağı (Alkol kullanan; U=16794, Uyuşturucu kullanan; $U=4988$, Tedavi gören; $U=3227$ ) yönündeki düşüncelerine ait puanlar diğer katılımcılardan daha düşükken bu bireylerle sohbet edip ilişki kurabileceklerine (Alkol kullanan; $U=15660$, Uyuşturucu kullanan; $U=4205$, Tedavi gören; $U=2681$ ) yönelik puanları daha yüksektir.

\section{Tartışma}

Çalışma kapsamında elde edilen verilerden ailesinde bağımlılık yapıcı madde kullanan birinin olması durumunda erkeklerin kadınlardan daha çok utanacağ 1 ve bu bireylerden kadınların daha çok korktuğu tespit edilmiştir. Yine çocuk sahibi olan katılımcıların ailesinde bağımlılık yapıcı madde kullanan birinin olması durumunda utanacağı yönündeki düşünceleri çocuk sahibi olmayan katılımcilardan daha yüksektir. Literatürde bu verilerle ilgili tespitlerde bulunan herhangi bir çalışmaya rastlanılmamıştır.

Konuyla ilgili yapılan çalışmalarda (Arıkan, Genç, Etik, Aslan ve Parlak, 2004) eğitim seviyesi düştükçe alkol ve madde bağımlısı bireylere yönelik etiketlemelerin arttığı bulunmuştur ancak bu çalışmanın bulgularıyla benzeşmemektedir. Eğitim seviyesi yükseldikçe katılımcıların bağımlı bireylere tedavi sürecinde yardımcı olabileceğine yönelik düşüncelerine ait puanlarının arttığı, aylık gelir düzeyi yükseldikçe katılımcıların bağımlı bireylere tedavi sürecinde yardımcı olabileceklerine yönelik tutumlarının ise azaldığı tespit edilmiştir. Yine aylık gelir düzeyi yükseldikçe katılımcıların, ailesinde bağımlılık yapıcı madde kullanan birinin olması durumunda utanacaklarına yönelik tutumları artmaktadır.

Ailesinde ve çevresinde alkol ve uyuşturucu madde kullanan, bağımlılık tedavisi görmüş yakını bulunan katılımcıların bağımlılık yapıcı madde kullanan bireylerle sohbet edip ilişki kurabilme oranlarının daha yüksek olduğu bulunmuştur. $\mathrm{Bu}$ veriler konuyla ilgili yapılan çalışmaları destekler niteliktedir (Boekel ve ark., 2015). Ayrıca katılımcıların alkol ve madde kullanımında arkadaş faktörünün etkili olduğunu düşünmesinin (\%81, $\mathrm{n}=321$ ) de bağımlılık yapıcı madde kullanan bireylerle sosyal ilişkiler kurma oranlarını azalttığı tespit edilmiştir. Yine ailesinde ve yakın çevresinde alkol ve uyuşturucu madde kullanan ve bağımlılık tedavisi görmüş birileri bulunan katılımcıların, diğer katılımcılara oranla bu bireyleri daha az tehlikeli olarak nitelendirdikleri ve bu bireylerden daha az korktukları tespit edilmiştir. Literatürde bu farklılığ 1 ele alan bir çalışmaya rastlanılmamıştır ancak birçok araştırmada bağımlılık yapıc1 madde kullanan bireylerin tehlikeli ve öngörülemez olarak tanımlandıkları ifade edilmektedir (Crisp, Gelder, Goddard ve Meltzer, 2005; Mushtaq, Mendes, Nikolaou ve Luty, 2015). Ronzani ve arkadaşları (2009) tarafindan yapılan bir araştırmada ise madde kullanan bireylerin tehlikeli olarak değerlendirilmesinin sosyal kaçınmanın ve izolasyonun artmasına neden olduğu belirtilmektedir.

Sigara, alkol ve uyuşturucu madde kullanmamış olan katılımcıların, bağımlılık yapıcı madde kullanan bireylerin tehlikeli olduğuna, bu bireylerin kendi hayatları ile ilgili doğru kararlar alamayacaklarına, suç işleme olasılıklarının yüksek olduğuna ve bu bireylerden uzak durmaya çalışacağına yönelik olumsuz tutumlarının diğer katılımcılardan daha yüksek olduğu saptanmıştır. $\mathrm{Bu}$ durum bağımlılı yapıcı madde kullanan katılımcıların benzer deneyimleri yaşamalarının empati duyma olasılıklarını arttırdığını ve dolayısıyla bu 
bireyleri etiketleme oranlarını azalttığını düşündürmektedir. Konuyla ilgili yapılan çalışmalarda bu sonucu destekler niteliktedir (Toronto Drug Strategy Implementation Panel, 2010). Dikkat çekici bir başka bulgu ise katılımcıların sigara, alkol ve uyuşturucu madde kullanım sıklıkları arttıkça yasa dışı madde kullanımını bir hastalık olarak görme oranlarının azalmasıdır.

Çalışma kapsamında bağımlılık yapıcı madde kullanan bireylere yönelik düşünce ve davranışlar üzerinde etkili olan faktörlerin, katılımcıların bu bireylere tedavi sürecinde yardım edebileceklerine yönelik düşünceleri üzerinde etkili olmadığı bulunmuştur. Konuyla ilgili yapılan araştırmalarda bağımlı bireylere yönelik olumsuz davranışlara rağmen bağımlılık tedavisinde katılımcıların yardım etme isteğinde olduğunu destekler niteliktedir (Ögel, 2002).

\section{Sonuç}

Bağımlılık sorunu nedenleri itibariyle bireyin içinde bulunduğu aile, sosyal çevre ve toplumdan etkilenen, sonuçları itibariyle bu dinamikleri etkileyen ve tedavi sürecinde de bu dinamiklerle bir arada ele alınması gereken çok boyutlu bir sorundur. Toplumun bağımlılık yapıcı madde kullanan bireylere yönelik ayrıştırıcı davranışları tedavi sürecini olumsuz etkilemektedir. Nitekim veri toplama sürecinde de araştırma konusunun madde bağımlılığı olmasından dolayı birçok kişinin araştırmaya katılmayı reddettiği, insanların madde bağımlılığı konusuna uzak durduğu ve önyargılı olduğu gözlemlenmiştir. Bağımlı bireylerin tedavi süreçlerinin kısalması ve toplumla bütünleşmesinin sağlanabilmesi için toplum destekli tedavi programlarının oluşturulması gerektiği düşünülmektedir. Araştırmamızın bulguları, bu programların oluşturulabileceğini destekler niteliktedir. Ayrica bu çalışma konusunun ulusal ölçekte yapılmasının, bağımlılığın tedavi sürecine yeni bakış açıları kazandıracağı ve bu alandaki politikaları geliştireceği düşünülmektedir.
Bağımlı bireylere yönelik ayrımcı tutumların en aza indirgenmesi, tedavi süreçlerinin daha etkili olması ve kısa sürede tamamlanabilmesi için bağımlı bireylerin toplumsal işlevlerini yerine getirebilmesinde sosyal hizmet disiplini, ayrımcılık karşıtı ve güçlendirme yaklaşımı uygulamalarıyla bu anlamda psikososyal müdahaleler yürütmekte ve bu alanlarda kamu politikalarının geliştirilmesine destek vermektedir. Bütüncül bir bakış açısına sahip olan sosyal hizmet disiplininin, çok boyutlu bir sosyal sorun olan madde bağımlılığı sorununun çözümlenmesinde önemli katkıları olacağ düşünülmektedir.

\section{Beyannameler}

Etik Onay ve katılım izni

Araştırma gerçekleştirilmeden önce Manisa Celal Bayar Üniversitesi Sosyal ve Beşeri Bilimler Bilimsel Araştırma ve Yayın Etiği Kurulu'ndan 26.12.2018 tarihli ve E.59590 sayılı kararla onay alınmıştır.

Yayın izni
Uygulanamaz

Veri ve materyallerin mevcudiyeti

Mevcut çalışma sırasında kullanılan veya analiz edilen veri kümeleri, talep üzerine ilgili yazardan temin edilebilir.

\section{Çıkar Çatışması}

Yazarlar çıkar çatışması olmadığını beyan eder.

\section{Finansman}

Uygulanamaz.

\section{Yazar Katkıları}

GY kuramsal çerçeveyi olușturmuş, veri toplamıs, toplanan verileri analiz etmiş ve yorumlamıştır. DY süpervizyon rolünü üstlenerek makalenin yazılmasında, veri analizinde ve yorumlanmasında büyük katkı sağlamıştır. Tüm yazarlar makalenin son halini okumuş ve onaylamıştır.

\section{Teșekkür}

Uygulanamaz.

\section{Kaynaklar}

Akgül, A., Kaptı, A. (2010). Türkiye'nin Uyuşturucu ile Mücadele Politikası: Politika Süreç Analizi. İçinde: Özeren S, Sözer MA, Demir OÖ, (Ed.), Yerelden Küresele Sınıraşan Suçlar kitabı içinde (s.75-99). Ankara: Polis Akademisi Yayınlarl.

Arıkan, Z., Genç, Y., Etik, Ç., Aslan, S., Parlak, İ. (2004). Alkol ve Diğer Madde Bağımlılıklarında Hastalar ve Yakınlarında Etiketleme, Bağımlılık Dergisi, 5(2), 52-56.

Bookel, L., Brouwers, E., Weeghel, J., Garretsen, H. (2015). Comparing stigmatising attitudes towads people with substance use disorders between the general public, GPs, mental health and addiction specialists and clients, International Journal of Social Psychiatry, 61(6), 539-549.

Corrigan, P.W., Kuwabara, S.A., O'Shaughnessy, J. (2009). The public stigma of mental illness and drug addiction: Findings from a stratified random sample, Journal of Social Work, 9(2), 139-147.

Crisp, A., Gelder, M., Goddard, E., Meltzer, H. (2005). Stigmatization of people with mental illnesses: a follow-up study within the changing minds campaign of the Royal College of Psychiatrists, World Psychiatry, 4(2), 106-113.

De Angelis, T. (1991). No one method better in treating addiction, The APA Monitor, October, p.10.
Dumas, L.G., Hennessey, M.B. (1999). The Varied Roles of Community Health Nursing. In E.H Janice, E.S Phyllis, A.T Sue (Eds.), Community Health Nursing Caring in Action (pp. 613617). 4. Edition, New York: Delmar Publishers.

Farley, O.W., Smith, L.L., Boyle, S.W. (2003). Introduction to Social Work. Boston: Allyn\&Bacon.

Galvani, S. (2015). Alcohol and other Drug Use: The Roles and Capabilities of Social Workers. England: Manchester Metropolitan University.

Husak, D.N. (2004). The moral relevance of addiction, Substance use \& misuse, 39(3), 399-436.

Işıı, M. (2013). Madde Kullanımı ve Stratejik İletişsim. Ankara: Sage Yayıncilı.

Klingemann, H.K. (1999). Addiction careers and careers in addiction, Substance Use Misuse, 34(11), 1505-1526.

Janulis, P.F. (2010). Understanding adddiction stigma: Examining desired social distance toward addicted individuals. (Master Theses). DePaul University, College of Liberal Ats and Social Sciences, Chicago-Illinois.

Lind, D.A., Marchal, W.G., Wathen, S.A. (2006). Basic statistics for business and economics. United States: McGraw-Hill Companies. 
Link, B.G., Phelan, J.C., Bresnahan, M., Stueve, A., Pescosolido, B.A. (1999). Public conceptions of mental illness: labels, causes, dangerousness, and social distance, American Journal of Public Health, 89(9), 1328-1333.

Meltzer, E.C., Suppes, A., Burns, S., Shuman, A., Orfanos, A., Sturiano, C.V., Fins, J.J. (2013). Stigmatization of substance use disorders among internal medicine residents, Substance Abuse, 34(4), 356-362.

Mushtaq, S., Mendes, V., Nikolaou, V., Luty, J. (2015). Analysis of the possible components of stigmatised attitudes towards depession and heroin dependence, Journal of Substance Use, 20(6), 399-406.

Okitikpi, T., Aymer, C. (2010). Key Concepts in AntiDiscriminatory Social Work. London: Sage.

Ögel, K. (2002). Türkiye'de Madde Bağımlılığı (2.bs). Ístanbul: IQ Kültür Sanat Yayıncılık.

Özden, S.Y. (1992). Uyuşturucu Madde Bağımlılı̆̆1 (1.bs). Istanbul: Nobel Tip Kitapevleri.

Ronzani, T., Higgins Biddle J., Furtado, E. (2009). Stigmatization of alcohol and other drug users by primary care providers in Southeast Brazil, Social Science \& Medicine, 69(7), 1080-1084.

Sevin, Ç., Erbay, E. (2008). Madde Bağımlılarının Tedavi Sonrası Sosyal Yaşamdaki Sorunları ve Sosyal Hizmet Uygulamaları, Bağımlılık Dergisi, 9(1), 36-40.

Sheafor, B.W., Horejsi, C.J. (2016). Sosyal Hizmet Uygulaması: Temel Teknikler ve İlkeler (Bilgen, A., Kaynarkaya, B., Gülmez, D., Baran Çiftci, D., Türközü, S.E., Çoban, F., Çelik, G., Özen, H., Uraz, O., Uraz, T., Oğuz, Y.S., Çev.). Ankara: Nika Yayınevi.
Tuncay, T., Ill, S. (2006). Sosyal hizmette baskı karşıtı uygulama: sosyal adalet paradigması temelinde bir özgürleştirme pratiği, Toplum ve Sosyal Hizmet, 17(2), 59-71.

Türkmen, S.N., Kumaşoğlu, Ç., Akyol, T. (2015). Alkol ve Madde Bağımlılı̆̆ Tedavi ve Eğitim Merkezi (AMATEM) Biriminde Yatan Bireylerde İçselleştirilmiş Damgalama ve Yaşam Kalitesi, Bağımlılık Dergisi, 16(4), 182-191.

Vatandaş, C., Can, B., Mahitapoğlu, H., Yaman, V., Kırbaşoğlu, Z. (2016). Türkiye'de Gençlik ve Uyușturucu Madde Sorunu, İstanbul: SEKAM Yayınları.

Tamar, D. (2001, Ekim). Psikoaktif madde kullananlara karşı halkın tutumu. 37. Ulusal Psikiyatri Kongresi: İstanbul, 29-30.

Toronto Drug Strategy Implementation Panel. (2010). Stigma, Discrimination and Substance Use: Experiences of people who use alcohol and other drug in Toronto, September. https://www.toronto.ca/wpcontent/uploads/2018/01/93e2stigmad iscrim_rep_2010_aoda.pdf Erișim Tarihi: 08.04.2019

TUBİM (Türkiye Uyuşturucu ve Uyuşturucu Bağımlılığı İzleme Merkezi), Bağımlılık Yapıcı Maddeler ve Bağımlılık İle Mücadele, 2019 Türkiye Raporu, Ankara: TUBİM.

United Nations Office on Drugs and Crime (UNODC), 2018 World Drug Report, Vienna.

Zastrow, C. (2014). Sosyal Hizmete Giriş ( A. Aykara, A. Beyazova, B. Yakut Çakar, C. Evren, Ç. Karaca, D. Baran Çiftci, E. Yıldırım, E. Bahşi, G. Albayrak, M. S. Birdal, S. Yağcıoğlu, S. Kurukafa, V. Yılmaz, (Çev.). Ankara: Nika Yayınevi. 